\title{
幼児期前期における嫌いな食べ物の質的変化に 関する縦断研究
}

\author{
會退 友美*1，赤松 利恵*1，杉本 尚子*2 \\ *1求茶の水女子大学大学院人間文化創成科学研究科 *2静岡県伊東市役所健康福祉部高龄者福祉課
}

\begin{abstract}
【目的】幼児期前期の子どもの嫌いな食べ物は，1歳６ヶ月児から３歳児にかけて变化するかを既存の縦断的データを用いて質的に検 討する。

【方法】静岡県伊東市保健センターにおいて，平成12年度から15年度に出生した子どもを対象に実施した，10 ヶ月児，1歳 6 ヶ月児, 3 歳児健康診査の全てを受診した1, 313人分の問診票データを利用した。項目は, 10 ケ月児の属性, 1 歳 6 ケ月児と 3 歳児の属性およ び好き嫌いの有無, 各年齢における嫌いな食べ物（自由記述）を用いた。また， 1 歳 6 ケ月児と 3 歳児の両方で好き嫌いがあった者 (以下，あり ああり）の内，嫌いな食べ物の内容を抽出して变化の内容を分類した。

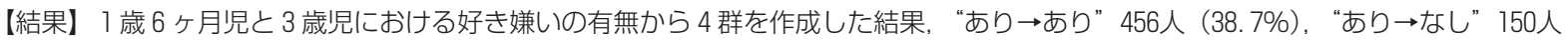
(12.7\%), “なし $\rightarrow$ 継続しているかを調べたところ，“嫌いな食べ物継続” 91 人 (7.7\%), 嫌いな食べ物が継続しなかった“嫌いな食べ物变化”は $154 人$ (13.0\%), “判断不能の者”211人 (17.9\%)の3 群に分けられた。

【結論】 1 歳 6 ヶ月児と 3 歳児の両年齢で好き嫌いがあると回答している場合でも, その約半数は嫌いな食べ物が変化しており, その 嫌いな食べ物の变化は多様であった。
\end{abstract}

栄養学䧱誌, Vol.71 No.6 323-329 (2013)

キーワード：幼児，嫌いな食べ物，縦断研究，内容分析

\section{I．緒言}

近年, 子どもの偏食を心配する母親が増加してい

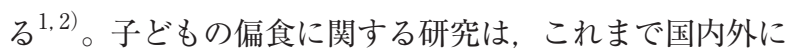
おいて数多く行われているが，偏食の明確な定義はない。 偏食は, 好き嫌いとして表現されることもあり, 実際に 乳幼児栄養調查 ${ }^{1)}$ では偏食, 幼児健康度調查 ${ }^{2)}$ では好き 嫌いが用いられており，この 2 つの言葉は同義語として 用いられることが多い。

白木ら ${ }^{3)}$ は, 偏食を「特定の食品を嫌って避けたり, 反対に特定の食品を好んでそれをよく食べるような食品 の取り方」と定義している。しかしながら, 多くの研究 者は偏食の中でも，嫌って食べないことを課題としてい る。たとえば, 村田ら ${ }^{4)}$ は, 子どもの偏食の有無と好き な食べ物，嫌いな食べ物との関連を調べた結果，好きな 食べ物の有無と偏食の有無に関連はみられなかったが, 嫌いな食べ物の有無と偏食には関連がみられたと報告し ている。また, 曽根 ${ }^{5)}$ は, 子どもの偏食について母親に たずねた調査を行い，母親の多くは「嫌って食べない」 ことを偏食ととらえていたと考察している。このことか ら, 子どもの偏食または好き嫌いの課題には, 子どもが 嫌いな食べ物に焦点を当てて検討することが求められて いる。
母親が子どもの好き嫌いを心配する理由には，これま での研究で，好き嫌いによって子どもの食事内容が悪く なることや，子どもの頃の好き嫌いがその後も継続する と報告されていることがあげられる。たとえば，好き嫌 いの継続に関連する研究では, $2 \sim 3$ 歳児の嗜好は 8 歳 の嗜好に影響しているといわれており，低年齢児からの 嗜好が重要であるとされている6)。また, Dubois ら ${ }^{7)}$ は, $2 \sim 4$ 歳の 3 年間のうち, 3 回とも好き嫌いがある と回答した者, 1 ～ 2 回好き嫌いがあると回答した者, 1 回も好き嫌いがなかった者の 4 歳児における食品摂取 を検討した結果，3回とも好き嫌いがあると回答した者 は，果物，野菜摂取が少なく，肉類の摂取も少なかった ことを示した。その他，2１1歳の子どもの好き嫌いを 調べた報告では，2 年以上好き嫌いが続いた者は，改善 した者に比べて，好みが強く，新しい食べ物を受け入れ ないことが示された ${ }^{8)}$ 。また，好き嫌いが継続する子の母 親の多くは，食事中の子どもとの関係が悪いことを報告 している ${ }^{5)}$ 。さらに，好き嫌いがある子どもは，母親に強 制的に食べさせられたという悪い記憶を有していたとの 報告もある ${ }^{9)}$ 。これらのことから，母親は，子どもの好き 嫌いがその後も継続して食生活に影響を与えると心配す るあまり，子どもに強制的に食べさせ，さらに子どもの 好き嫌いを導くという悪循環に陥りやすいといえる。

連絡先 : 赤松利恵 $\overline{1} 112-8610$ 東京都文京区大塚2-1-1 打茶の水女子大学大学院人間文化創成科学研究科 電話 03-5978-5680 FAX 03-5978-5680 E-mail akamatsu.rie@ocha.ac.jp 
しかし, これらの研究は, 好き嫌いの有無によって継 続性を検討しており，実際に嫌いな食べ物が継続するか を検討していない。つまり, 嫌いな食べ物の継続性を調 べていない。幼児期の好き嫌いの有無のみでとらえるの ではなく, 食べ物の内容まで調べることにより, 幼児期 の好き嫌いは流動的であるかを検討できる。そこで，本 研究の目的は, 幼児期前期の好き嫌いの変化について, 嫌いな食べ物の継続性, 特に野菜に焦点をあて, 縦断的 既存データを用いて質的な検討を行うこととした。

\section{II. 方 法}

\section{1. 調 査 概 要}

本研究の対象地域は, 静岡県伊東市である。伊東市は, 面積124.13平方キロメートル, 伊豆半島の最東部に位置 している。本研究の調査期間（平成 12 年～15年）の人口 は, 約 7 万 5 千人であった。豊富な温泉と自然環境に恵 まれ，市民の 8 割が観光を中心とした第三次産業に従事 している。首都圈からの中高年者の移住者もあり, 急速 に少子高齢化が進んでいる。

本研究では, 平成 12 年度から 15 年度に出生した 2,323 人の児を対象とした。静岡県伊東市保健センターが用い ている，10 ケ月児， 1 歳 6 ケ月児と 3 歳児健康診査の問 診票が揃う 1,313 人分 $(56.5 \%)$ について先行研究 ${ }^{10)}$ で 収集したデータを用いて 2 次解析を行った。問診票は, 主に家庭で育児に携わる者が記入するように作成され， 健康診査 1 ケ月前のお知らせとともに対象者の家庭に郵 送された。回答済みの問診票を健康診査当日に持参して もらい, 問診で活用されている。本研究では, 10 ケ月児 の問診票から属性, 1 歳 6 ケ月児, 3 歳児からは属性お よび好き嫌いの項目を用いた。

なお，本研究は，伊東市情報公開条例に従って手続き を行い, 決定通知書を受けた後, 氏名, 住所, 電話番号, 医療機関名を削除した問診票を使用した。また, 本研究 は, お茶の水女子大学生物医学的研究の倫理特別委員会 の承認を得ている。

\section{2. 調査項目}

1）好き嫌い

好き嫌いについては, 1 歳 6 ケ月児と 3 歳児でたずね ており，教示は，“好き嫌いはありますか”であった。回 答は, “ない”, “ある”, “激しい”の3 段階であった。ま た，特に好きな食べ物と特に嫌いな食べ物をそれぞれ回 答する自由記述の欄があり, 本研究では, 特に嫌いな食 べ物の項目を用いた。

\section{2）属性}

子どもの属性については, 10 ヶ月児の問診票から性 別, 出生順位, 1 歳 6 ケ月児, 3 歳児からきょうだい数 の項目を用いた。子どもの体格は，1歳 6 ケ月児と 3 歳 児の問診票から得られた身長と体重の結果を用いて肥満 度を算出して評価した。肥満度 $=($ 実測体重 $[\mathrm{kg}]-$ 標準体 重 $[\mathrm{kg}])$ ／標準体重 $[\mathrm{kg}$ をを用いた。標準体重は，平成12 年乳幼児身体発育調査報告書 ${ }^{11)}$ に記載された式を用いて 算出した。

男児 : $Y=2.06 \times 10^{-3} X^{2}-0.1166 X+6.527$,

女览 : $\mathrm{Y}=2.49 \times 10^{-3} \mathrm{X}^{2}-0.1858 \mathrm{X}+9.0360$

$(\mathrm{Y}=$ 標準体重 $[\mathrm{kg}], \mathrm{X}=$ 身長 $[\mathrm{cm}])$ 。

肥満度は， $-15 \%$ 以下を「やせ」， - 15\% 15\%未満 を「標準」，15\% 以上を「肥満」とし， 3 群に分類し $た^{12)}$ 。

家族の属性に関する項目は, 1 歳 6 ヶ月児と 3 歳児の 問診票から母親, 父親の年齢, 祖父母の同居の有無, 母 親の就業の有無を用いた。

\section{3. 解析方法}

まず，各項目の記述統計を求めて分布を確認した。次 に, McNemar 検定を用いて 1 歳 6 ケ月児と 3 歳児の好 き嫌いの変化を調べた。続いて，横断的にそれぞれの年 齢で子どもと保護者の属性と好き嫌いに関連があるかを 検討し, さらに $\chi^{2}$ 検定, $t$ 検定を用いて 1 歳 6 ケ月览の 属性と 3 歳児の好き嫌いの有無について調べた。また,

1 歳 6 ケ月児の好き嫌いが肥満度の変化に関連があるか を調べるため, 1 歳 6 ケ月览の好き嫌いの有無を独立変 数とし, 1 歳 6 ケ月児から 3 歳児までの肥満度の変化量 について, $t$ 検定を用いて比較した。

その後, 1 歳 6 ヶ月児と 3 歳児の嫌いな食べ物の内容 （自由記述）について 1 名の研究者が同じような回答をま とめてカテゴリ化し,さらに別の研究者 1 名が内容を確 認した。まず，“1歳 6 ケ月児好き嫌いあり $\rightarrow 3$ 歳児好き 嫌いあり”の内, 1 歳 6 ケ月児と 3 歳児の嫌いな食べ物 の内容を検討し，嫌いな食べ物が継続しなかった者の記 述内容を調べた（例：「豆腐」、「トマト，牛乳」の豆腐 を継続しなかった食べ物としてカウント)。本研究では, 子どもの嫌いな食べ物としてあげられる野菜に焦点をあ て，3歳児における嫌いな食べ物が野菜か野菜以外かに 分類し, 1 歳 6 ヶ月児からの変化を分析した。さらに, 嫌いな食べ物の個数の変化と食べ物の内容の変化を調べ

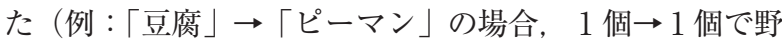
菜以外 $\rightarrow$ 野菜)。次に, 両年齢ともに好き嫌いがあり, 同 一の嫌いな食べ物を回答した者の継続した嫌いな食べ物 を述べ人数で調べた。その際，嫌いな食べ物が複数あり， 
その一部が継続した場合も，継続した食べ物をカウント

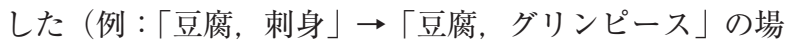
合，豆腐を継続した食べ物としてカウント)。

以上の解析は, 全て SPSS 19. 0 ver for Windows（日本 アイ・ビー・エム株式会社）を使用し，有意水準は $5 \%$ とした（両側検定）。

\section{III. 結 果}

\section{1. 属性}

3 歳児健康診査時における母親の平均年齢（標準偏差） は, 32.2 (4.5) 歳であり, 父親の年齢は34.5（5.6）歳 であった。子どもの性別は男児 664 人 (50.6\%), 女児 648人（49.4\%）であり， $49.0 \%$ が第 1 子であった。祖 父母と同居する家庭は 1 歳 6 ケ月児と 3 歳児とも約 3 割 であった。また, 就業がある母親は, 1 歳 6 ケ月児と 3 歳児でそれぞれ約 3 割と約 4 割であった（表 1 )。

2. 1 歳 6 ケ月児と 3 歳児における好き嫌いの有無と 属性との関連

1 歳 6 ケ月児の好き嫌いの状態は，“ない”が 617 人 (48.2\%)，“ある”が625人 (48.9\%)，“激しい”が38人 (3.0\%) であった。3 歳児では, “ない”が 496 人 (41.2\%)，“ある”が674人 (55.9\%)，“激しい”が35人 (2.9\%) であった。以降の分析では，好き嫌いが“ある” または“激しい”と回答した者を“好き嫌いあり”（1歳 6 ケ月児 663 人 $(51.8 \%), 3$ 歳児 709 人 $(58.8 \%))$ と し，“ない”と回答した者を“好き嫌いなし”として 2 群 に分類した。

続いて, 子どもと保護者の属性と 1 歳 6 ケ月児, 3 歳 児における好き嫌いの有無について横断的に関連を検討 した。その結果, 1 歳 6 ケ月児では, 好き嫌いがない子 の方が，好き嫌いがある子に比べて出生順位（平均值 (標準偏差)）が低かった（好き嫌いなしvs 好き嫌いあ り : $1.7(0.8)$ 子 vs $1.6(0.7)$ 子, $p=0.049)$ 。また, 祖父母との同居では，好き嫌いがない子の方が祖父母と 同居していた（好き嫌いなしvs 好き嫌いあり：35.2\% vs $28.8 \%, p=0.016) 。$ 一方， 3 歳巟では，好き嫌いと 属性に関連はみられなかった。

それぞれの年齢における肥満度の平均值（標準偏差） は, 1 歳 6 ケ月児 $2.2(7.6) \% ， 3$ 歳児 2.5 (7.5) \% で あった。さらに，1歳 6 ケ月児における好き嫌いが 1 歳 6 ヶ月児から 3 歳児の肥満度の変化に関連するかを調べ るため, 1 歳 6 ケ月児から 3 歳児の肥満度の変化量につ いて，1歳 6 ケ月児の好き嫌いの有無で比較した結果 (平均値 (標準偏差)), 有意な差はみられなかった（好き
表 1 対象者の属性

\begin{tabular}{|c|c|c|}
\hline & 人 & $\%$ \\
\hline \multicolumn{3}{|l|}{ 子どもの性別 } \\
\hline 女览 & 648 & 49.4 \\
\hline 男児 & 664 & 50.6 \\
\hline \multicolumn{3}{|c|}{ 出生順位（10 ヶ月巟） } \\
\hline 第 1 子 & 643 & 49.0 \\
\hline 第 2 子 & 501 & 38.2 \\
\hline 第 3 子 & 139 & 10.6 \\
\hline 第 4 子 & 25 & 1.9 \\
\hline 第 5 子 & 5 & 0.4 \\
\hline \multicolumn{3}{|c|}{ きょうだい数（１歳 6 ケ月児） } \\
\hline 1 人 & 585 & 44.6 \\
\hline 2 人 & 541 & 41.2 \\
\hline 3 人 & 152 & 11.6 \\
\hline 4 人 & 27 & 2.1 \\
\hline 5 人 & 7 & 0.5 \\
\hline \multicolumn{3}{|c|}{ きょうだい数（3 歳児） } \\
\hline 1 人 & 372 & 28.4 \\
\hline 2 人 & 690 & 52.8 \\
\hline 3 人 & 205 & 15.7 \\
\hline 4 人 & 33 & 2.5 \\
\hline 5 人 & 8 & 0.6 \\
\hline \multicolumn{3}{|c|}{ 子どもの肥満度（1 歳 6 ケ月児） } \\
\hline やせ & 10 & 0.8 \\
\hline 標準 & 1,238 & 94.5 \\
\hline 肥満 & 62 & 4. 7 \\
\hline \multicolumn{3}{|c|}{ 子どもの肥満度（3 歳児） } \\
\hline やせ & 2 & 0.2 \\
\hline 標準 & 1,231 & 94.3 \\
\hline 肥満 & 72 & 5.5 \\
\hline \multicolumn{3}{|c|}{ 祖父母との同居（１歳 6 ヶ月児） } \\
\hline している & 418 & 31.9 \\
\hline していない & 894 & 68. 1 \\
\hline \multicolumn{3}{|c|}{ 祖父母との同居（ 3 歳児） } \\
\hline している & 428 & 32.6 \\
\hline していない & 883 & 67.4 \\
\hline \multicolumn{3}{|c|}{ 母親の就業（１歳 6 ケ月児） } \\
\hline 働いている & 384 & 32.3 \\
\hline 働いていない & 804 & 67.7 \\
\hline \multicolumn{3}{|c|}{ 母親の就業（ 3 歳児） } \\
\hline 働いている & 500 & 42.9 \\
\hline 働いていない & 665 & 57.1 \\
\hline
\end{tabular}

欠損值は項目ごとに除外した。

嫌いなし vs 好き嫌いあり：0.4（4.9）\% vs 0.2 (4.9)\%， $p=0.441) 。 つ ま り, 1$ 歳 6 ヶ月児の子どもの好き嫌いの 有無と 1 歳 6 ケ月児から 3 歳の体格の変化には関連がみ られなかった。

3. 1 歳 6 ヶ月児と 3 歳児における好き嫌いの変化

1 歳 6 ケ月児と 3 歳児ともに好き嫌いの有無を回答し た 1,178 名の好き嫌いの有無の変化を McNemar 検定に よって検討した結果，有意に人数分布が変化したことが 
示された $(p<0.01)$ 。それぞれの人数は, 図 1 に示す通 り, “1 1 歳 6 ケ月児好き嫌いなし $\rightarrow 3$ 歳児好き嫌いなし” 339 人 $(28.8 \%), “ 1$ 歳 6 ケ月児好き嫌いあり $\rightarrow 3$ 歳児好 き嫌いあり”456人 $(38.7 \%)$ ，“1歳 6 ケ月児好き嫌いあ り $\rightarrow 3$ 歳児好き嫌いなし”150人 (12.7\%), “1歳 6 ヶ月 児好き嫌いなし $\rightarrow 3$ 歳児好き嫌いあり”233人（19.8\%） であった。

“ 1 歳 6 ケ月児好き嫌いあり $\rightarrow 3$ 歳児好き嫌いあり”の 456 人は, 雨年齢ともに同じ嫌いな食べ物を記入した“嫌 いな食べ物継続” 91 人 $(7.7 \%)$ ，嫌いな食べ物が継続し

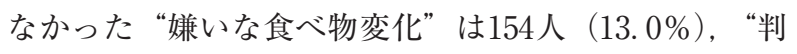
断不能の者” 211 人 (17.9\%) の3 群に分けられた。判断 不能の者とは, 嫌いな食べ物の自由記述がない（125人), またはトマトから野菜に変化するなどの判断がつかな かった者（86人）を指す。

以上のことから, 好き嫌いの有無または内容に変化が

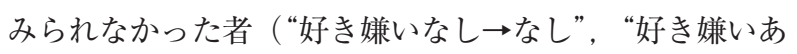

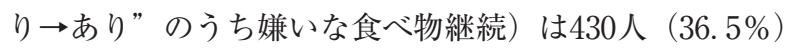
であった。一方，好き嫌いの有無または内容に変化がみ られた者（“好き嫌いあり 市り”のうち嫌いな食べ物の 内容が変化, “好き嫌いあり り”)は537人 (45.6\%) であった。

3. 好き嫌いが継続した者の内, 嫌いな食べ物が変化 した者の記述内容の検討

“ 1 歳 6 ケ月児好き嫌いあり $\rightarrow 3$ 歳児好き嫌いあり” 456 人の内, 嫌いな食べ物が変化した 154 人の記述内容を 調べた。1歳 6 ケ月児で嫌いであった食べ物を抽出した 結果, 延べ183件が得られ, 最も多かった変化した食べ物 は野菜類の 53 件 $(23.0 \%)$ であり, 続いて肉類が 25 件 (13.7\%), いも類が14件（7.7\%）であった。その他,
ぼそぼそしたものなどの食感, 酸っぱいものなどの味, 色が濃いものなどの色に関する回答もみられた。さらに， 回答者それぞれの変化内容を調べるため,「その時によ る」などを回答した者を除外した 126 人の回答した個数を 数えた。その結果, 1 個 $\rightarrow 1$ 個 75 人, 1 個 $\rightarrow 2$ 個 31 人, 2 個 $\rightarrow 1$ 個 17 人, 2 個 $\rightarrow 2$ 個 2 人であった。嫌いな食べ 物が 1 個ずつであった者の結果を表 2 に示す。表 2 の通 り, 嫌いな食べ物が 1 個の者の内容の変化では, 野菜の 種類が変わった者が 20 人と最も多く, 続いて野菜から野 菜以外の食べ物に変わった者が多かった（表 2$)$ 。 1 個 $\rightarrow$ 2 個へ変化した者（31人）では，トマトが増えた者が最 も多く (10人), 続いて野菜, ピーマンが各 5 人であっ た。 2 個 $\rightarrow 1$ 個へ変化した者（17人）では，野菜から別 の野菜に変化した者はおらず, 全く異なる食べ物に変化 しており，野菜以外の物が嫌いであった者が野菜を嫌い

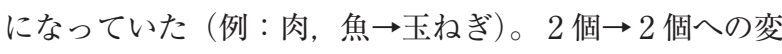
化した 2 人の内容は, 豆, いも $\rightarrow$ 練り製品, 野菜と肉, 魚 $\rightarrow$ ピーマン, ほうれん草であった。

4. 好き嫌いが継続した者の内, 嫌いな食べ物が継続 した者の記述内容の検討

次に, “ 1 歳 6 ケ月児好き嫌いあり $\rightarrow 3$ 歳児好き嫌いあ り”456人の内，嫌いな食べ物が継続したと回答した者は 91人であった（延べ99件）。その91人が回答した内容を分 類した結果，継続した嫌いな食べ物が 1 個であった者は 85 人， 2 個は 5 人， 4 個は 1 人であった。継続した嫌い な食べ物が 1 個であった者の内容を分類した結果, 野菜 22 人 $(25.9 \%)$, ピーマン 6 人 $(7.1 \%)$ トマト, 葉野菜 各 5 人 $(5.9 \%)$ など, 野菜が 52 人 $(61.2 \%)$ と最も多 かった。次いで, 肉 12 人 $(14.1 \%)$ が多くみられ, 続い て，牛乳，くだものが各 6 人 $(7.1 \%)$ であった（表 3$) 。$

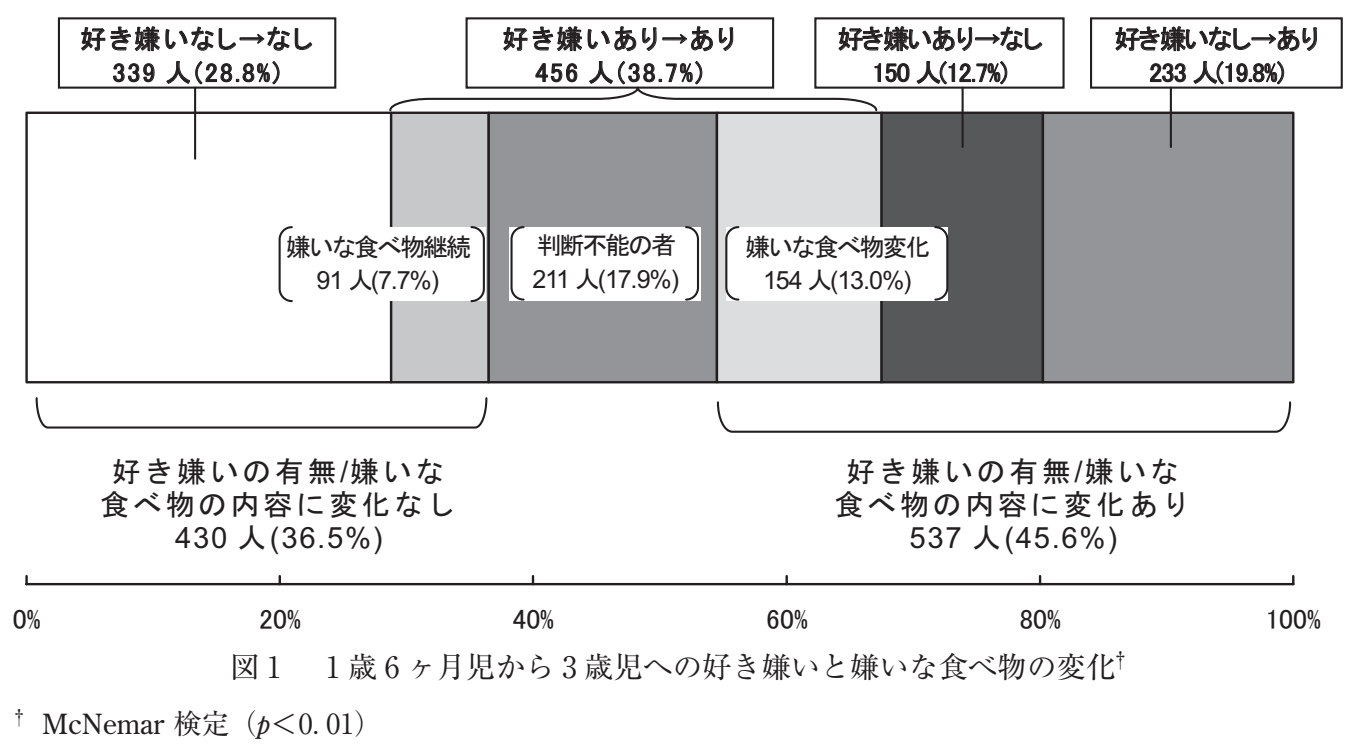


表 2 嫌いな食べ物が変化した者の内容の組み合わせ

\begin{tabular}{|c|c|c|c|c|}
\hline 1 歳 6 ケ月児 & 3 歳児 & 例 & 人 & $\%$ \\
\hline \multirow[t]{2}{*}{ 野菜 } & 野菜 & レタス $\rightarrow$ ピーマン & 20 & 26.7 \\
\hline & 野菜以外 & トマト $\rightarrow$ & 13 & 17.3 \\
\hline \multirow[t]{2}{*}{ 肉 } & 野菜 & 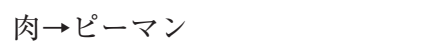 & 8 & 10. 7 \\
\hline & 野菜以外 & 肉 $\rightarrow$ 揚げもの & 2 & 2.7 \\
\hline \multirow[t]{2}{*}{ ごはん } & 野菜 & 白飯 ートマト & 2 & 2.7 \\
\hline & 野菜以外 & 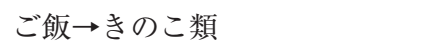 & 4 & 5.3 \\
\hline \multirow[t]{2}{*}{ くだもの } & 野菜 & バナナーはくさい & 4 & 5.3 \\
\hline & 野菜以外 & すっぱい果物 $\rightarrow$ 納豆 & 1 & 1. 3 \\
\hline \multirow[t]{2}{*}{ 卵 } & 野菜 & 卵ななす & 3 & 4. 0 \\
\hline & 野菜以外 & 卵 $\rightarrow$ 肉 & 2 & 2.7 \\
\hline \multirow[t]{2}{*}{ wも } & 野菜 & いも類 $\rightarrow$ 葉物 & 3 & 4. 0 \\
\hline & 野菜以外 & 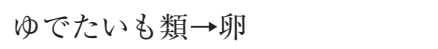 & 1 & 1. 3 \\
\hline 牛乳 & 野菜 & 牛乳 ヤトマト & 3 & 4. 0 \\
\hline \multirow[t]{2}{*}{ 魚 } & 野菜 & 魚 $\rightarrow$ 野菜類 & 1 & 1.3 \\
\hline & 野菜以外 & 刺身 $\rightarrow$ 納豆 & 1 & 1. 3 \\
\hline 納豆 & 野菜以外 & 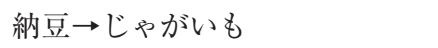 & 2 & 2.7 \\
\hline 豆腐 & 野菜 & 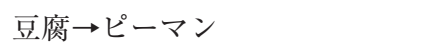 & 2 & 2. 7 \\
\hline ケチャップ & 野菜 & ケチャップのついたもの 野菜 & 2 & 2.7 \\
\hline 海藻 & 野菜 & ひじき $\rightarrow$ 生トマト & 1 & 1.3 \\
\hline
\end{tabular}

$n=75$, 嫌いな食べ物の変化が 1 個の者を分析対象とした。

表 3 嫌いな食べ物が継続した者の食べ物の内容

\begin{tabular}{lcc}
\hline & 人 & $(\%)$ \\
\hline 野菜 $^{\text {肉 }}$ & 52 & $(61.2)$ \\
牛乳 & 12 & $(14.1)$ \\
くだもの & 6 & $(7.1)$ \\
納豆 & 6 & $(7.1)$ \\
ごはん & 3 & $(3.5)$ \\
魚 & 1 & $(1.2)$ \\
パン & 1 & $(1.2)$ \\
豆腐 & 1 & $(1.2)$ \\
ケーキ & 1 & $(1.2)$ \\
固いもの & 1 & $(1.2)$ \\
\hline
\end{tabular}

$n=85$ ，嫌いな食べ物が 1 個であった者を分析対象と した。

†野菜 22 人 $(25.9 \%)$, ピーマン 6 人 $(7.1 \%)$, トマ 卜 5 人 $(5.9 \%)$, 葉野菜 5 人 $(5.9 \%)$, 生野菜 4 人 $(4.7 \%)$, ほうれん草 2 人 $(2.4 \%)$, 緑の野菜 2 人 $(2.4 \%)$ ，なす 2 人 $(2.4 \%)$, ブロッコリー 2 人 $(2.4 \%)$ ，にんじん 1 人 $(1.2 \%)$ ，ねぎ 1 人 (1. $2 \%)$

2 個継続した者の嫌いな食べ物は, トマトと肉が各 2 人 であり, ピーマン, ほうれん草, 納豆, 卵, 魚, 米が各 1 人であった。 4 個継続した者の内容は, 野菜, マヨ ネーズ, チーズ, ホワイトソースであった。

\section{N. 考 察}

本研究は, 幼児期前期における好き嫌いの状態につい て縦断的に検討した結果，両年齢で好き嫌いがみられた としても, その約半数は嫌いな食べ物が変化しており, その内容の変化は多様であることを報告した。

本研究で嫌いな食べ物を縦断的に分析した結果, 1 歳 6 ケ月児から 3 歳児において, 必ずしも嫌いな食べ物が 継続しているわけではないことが示された。幼児期前期 の好き嫌いは精神的, 身体的発達の変化によって急激に 増加するため, この時期の子どもをもつ母親は, 子ども の好き嫌いを心配する者が多い。Batsell ら ${ }^{13)}$ は，大学生 を対象に子どもの頃に無理やり食べさせられた嫌な思い 出を後ろ向きに調查した。その結果，参加者のうち $76 \%$ が親や教師などから無理やり食べさせられる経験を有し ており，そのうち， $72 \%$ が現在もその食べ物を食べない と回答したことを報告した。このことから，子どもの好 き嫌いを心配するあまり保護者が強制的に食べさせるよ うな関わりは，その後の子どもの食嗜好や食行動に影響 を与える可能性がある。本研究の結果を用い，現時点の 嫌いな食べ物を気に掛け過ぎるのではなく，少し長い目 で捉えるように促すことで，無理やり食べさせる行動に 働きかけることができるだろう。

さらに本研究では, 嫌いな食べ物の変化は, 多様であ ることが示された。また，好き嫌いが継続した者の 1 歳 
6 ケ月児と 3 歳児における嫌いな食べ物の変化を調べた ところ, 約半数の者で嫌いな食べ物が变化していた。ま た, 嫌いな食べ物は野菜類が多くみられたが, その中で もレタスからピーマンなど野菜の種類が変わる者や野菜 以外の他の食品との組み合わせもみられたことから, 個 人でそれぞれ嗜好が異なることが示唆された。つまり， 幼児期前期の嗜好とその変化には多様性があるといえる。 また, 約 2 割の子どもにおいて，3歳児で新たに嫌いな 食べ物が出現していた。これは, 子どもが新しい食物に 出会う, 自己表現ができるなど, 社会的, 精神的発達の 証しといえる。

本研究の限界点として, 分析に用いたデータは, 自己 申告による自由記述であったことがあげられる。よって， 両年歯令で嫌いな食べ物を対応させる際の判断が難しい回 答があった。また, “野菜 $\rightarrow$ 野菜”と回答した者を“嫌い な食べ物継続” と判断したが, 野菜と回答した者の詳細 な食品はわからない。本研究の限界点を考慮して結果を 解釈する必要がある。しかしながら, 自由記述であった ことにより，選択肢を設けた調査では拾いあげることが できない回答者が感じているままの回答が得られたこと は本研究の強みである。

\section{V. 結 論}

本研究は, 幼児期前期の子どもの好き嫌いが継続して も, その約半数の嫌いな食べ物は変化しており, その変 化は多様であることをはじめて報告した。

\section{謝辞}

本研究の遂行に際し, データ収集のご協力を賜りまし た静岡県伊東市保健福祉部健康増進課（現健康福祉部健 康医療課）の職員の皆様に厚く御礼申し上げます。また, 本論文執筆にあたり，ご助言をいただきましたお茶の水 女子大学大学院人間文化創成科学研究科教授藤原葉子先 生, 教授森光康次郎先生, お茶の水女子大学生活環境教 育研究センターSHOKUIKU 総合研究部門准教授石川朋 子先生に心より御礼申し上げます。最後に, データの入 力にご協力いただいた, お茶の水女子大学生活科学部食 物栄養科学科佐藤祥瑚さん, 下須賀沙季さん, 外山未來 さん, 吉田千夏さんに心より感謝いたします。

\section{利益相反}

利益相反に相当する事項はない。

\section{文献}

1）厚生労働省 : 平成 17 年度乳幼児栄養調查結果の概要, http://www.mhlw.go.jp/houdou/2006/06/h0629-1.html, （2013年10月22日）

2）日本小児保健協会：幼児健康度に関する継続的比較研 究, http://plaza.umin.ac.jp/ jschild/book/pdf/2010_ kenkochousa.pdf, （2013年10月22日）

3）白木まさ子, 大村雅美, 丸井英二 : 幼児の偏食と生活 環境との関連，民族衛生，74,279-289（2008）

4）村田 務, 林 薰, 染谷麻子 : 幼児の偏食と保護者の 対応に関する調查, 白梅学園短期大学紀要, 39, 113-127 (2003)

5）曽根眞理枝 : 幼览の食事に関する母親の意識と対応一 偏食の視点からの考察一, 横浜女子短期大学紀要, 21, 85100 (2006)

6) Skinner, J.D., Carruth, B.R., Wendy, B., et al.: Children's food preferences: a longitudinal analysis, J. Am. Diet. Assoc., 102, 1638-1647 (2002)

7) Dubois, L., Farmer, A.P., Girard, M., et al.: Preschool children's eating behaviours are related to dietary adequacy and body weight, Eur. J. Clin. Nutr., 61, 846-855 (2007)

8) Mascola, A.J., Bryson, S.W., Agras, W.S.: Picky eating during childhood: a longitudinal study to age 11 years, Eat. Behav., 11, 253-257 (2010)

9) Galloway, A.T., Fiorito, L., Lee, Y., et al.: Parental pressure, dietary patterns, and weight status among girls who are "picky eaters", J. Am. Diet. Assoc., 105, 541-548 (2005)

10）会退友美, 秋山陽子, 赤松利恵, 他：離乳期の子ども の間食に関する縦断研究一離乳期の菓子類摂取と幼児期 の間食一，栄養学雑誌，68,8-14（2010）

11）厚生労働省雇用均等 - 児童家庭局 : 平成12年乳幼児身 体発育調査報告書, http://www.mhlw.go.jp/houdou/ 0110/h1024-4.html，（2013年10月22日）

12）日本肥満学会編：小児の肥満症マニュアル, p. 120 （2004）医歯薬出版, 東京

13) Batsell, W.R. Jr, Brown, A.S., Ansfield, M.E., et al.: "You will eat all of that!": a retrospective analysis of forced consumption episodes, Appetite, 38, 211-219 (2002)

(受付：平成 25 年 3 月 7 日，受理：平成 25 年 10 月 22 日) 


\title{
Longitudinal Study of Qualitative Changes in Disliked Foods in Early Childhood
}

\author{
Tomomi Ainuki*1, Rie Akamatsu*1 and Naoko Sugimoto*2 \\ ${ }^{* 1}$ Graduate School of Humanities and Sciences, Ochanomizu University \\ *2Ito City, Health and Welfare Department, The Elderly Welfare Division
}

\begin{abstract}
Objective: To examine changes in disliked foods in early childhood (from 18 to 36 months old) using longitudinal qualitative data.

Methods: Children $(n=1,313)$ born between April 2000 and March 2004 were enrolled in Ito City(Shizuoka, Japan). Data $(n=1,313)$ from the children's health checkups conducted at 10, 18 and 36 months of age at the Ito City health center were used for the analysis. We analyzed demographic data at 10,18, and 36 months old, the existence or non-existence of food preferences and free descriptions of disliked foods at 18 and 36 months old. We extracted the content of disliked foods and classified the changes of the content at both age (existence $\rightarrow$ existence).

Results: Food-preference results at 18 and 36 months were classified into four groups: 456 (38.7\%) as "existence $\rightarrow$ existence," $150(12.7 \%)$ as "existence $\rightarrow$ non-existence," $233(19.8 \%)$ as "non-existence $\rightarrow$ existence" and 399 (28.8\%) as "non-existence $\rightarrow$ non-existence." In the "existence $\rightarrow$ existence" group, who reported disliked food at both ages, these food dislikes remained. Members of the "existence $\rightarrow$ existence" group were classified into the following groups: 91 (7.7\%) as "continuance," 154 (13.0\%) as "non-continuance," 211 (17.9\%) as "non-estimation."

Conclusion: Nearly half of the participants who reported the existence of a food preference at 18 and 36 months years of age changed their disliked foods; many of them made multiple food-preference changes.
\end{abstract}

Jpn. J. Nutr. Diet., 71 (6) 323 329 (2013)

Key words: infant, disliked food, longitudinal study, content analysis 